\title{
Educating in the East, Emigrating to the West?
}

\author{
d'Artis Kancs Julda Kielyte
}

\section{EERI Research Paper Series No 01/2010}

ISSN: 2031-4892

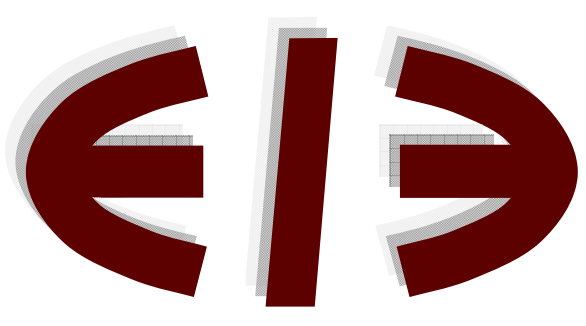

\section{EERI}

Economics and Econometrics Research Institute Avenue de Beaulieu 1160 Brussels

Belgium

Tel: +3222993523

Fax: +322 2993523

www.eeri.eu 


\title{
Educating in the East, Emigrating to the West?*
}

\author{
d'Artis Kancs $^{\dagger} \quad$ Julda Kielyte ${ }^{\ddagger}$
}

January 2010

\begin{abstract}
This paper examines the potential impacts of East-West migration of talents on the innovative capital and hence the long-run growth prospects in Eastern sending countries. Complementing previous studies, we examine the impact of high skill migration not only on the formation of human capital, but also consider migration's impact on knowledge capital in the sending countries. In line with previous studies we find that in the short- to medium-term high skill migration strictly reduces national innovative capital and hence increases the gap between East and West. However, these effects might be mitigated by factors such as reinforced education of workers, productive investment of remittances, return migration and increased knowledge transfer. Given that the emigration of highly skilled affects human capital differently than knowledge capital, addressing the adverse impacts of the most talented and highly skilled worker emigration efficiently, differentiated policies are required for human capital and knowledge capital.
\end{abstract}

Keywords: International labour migration, skilled workers, growth, human capital.

JEL classification: D50, D80, F22, F24, H52, I21, J24, J61, O15.

${ }^{*}$ The authors acknowledge helpful comments from Pavel Ciaian, participants of the ESPE and ERSA conferences in Seville and Lodz, the Research Network 1989 workshop participants in London and Florence. The authors acknowledge financial support from the Research Grant 'International Labor Migration in a Globalizing Economy'. The views expressed in this paper are purely those of the authors and may not in any circumstances be regarded as stating an official position of the European Commission.

${ }^{\dagger}$ European Commission (DG Joint Research Centre), Catholic University of Leuven (LICOS), and Economics and Econometrics Research Institute (EERI). E-mail: d'artis.kancs@ec.europa.eu.

${ }^{\ddagger}$ European Commission (DG Economic and Financial Affairs), London School of Economics, and Economics and Econometrics Research Institute (EERI). E-mail: kielyte@lse.ac.uk. Correspondence Address: European Commission, DG JRC, B-1049 Brussels, Belgium. 


\section{Introduction}

European integration increases the mobility of skilled workers, which increased the emigration of talents from the East to the West. ${ }^{1}$ The emigration of the most talented and skilled population in turn affects knowledge and human capital in the East European sending countries, and hence the development gap between East and West. On the one hand, the reduced innovative capital limits the catching-up possibilities for the Eastern sending countries. On the other hand, the immigration of high skill workers adds to the productive pool of human capital in the Western receiving countries.

The present study examines how skill emigration has affected one of the key long-run growth determinants - knowledge capital - in the East European sending countries since the fall of the Wall. Studying the effects of skill emigration to the West on knowledge capital in the East, the paper is among the first focusing on the Eastern sending countries and examining the long-run growth impacts of skill emigration on human capital in an integrated innovative capital framework.

The conceptual framework of our study is based on the Kancs and Ciaian (2010) model of innovative capital which. According to Kancs and Ciaian, human capital depends on the size of educated workforce and international movements of skilled workers. The empirical approach, which we adopt for studying the migration's impact on these two key determinants of human capital, is pragmatic and largely descriptive because, due to data limitations, a robust econometric analysis is not possible.

\section{Migration in divided Europe}

\subsection{Migration in the West}

In the period after 1945 when the direct aftermath of the second World War caused massive population movements in Europe. At that time two parts of Europe started to live separate lives: on the one side Western Europe and on the other Eastern Europe. During the period of the post war reconstruction, immigration into Western Europe consisted mainly of 'displaced persons' from Eastern Europe. In this period the national immigration policies of Western European receiving countries could broadly be classified in two types: rotational migration policies and permanent migration policies. Switzerland and West Germany adopted a rotational system of immigration

\footnotetext{
${ }^{1}$ In a narrow sense East is referred to as the CEE accession countries, which include Bulgaria, the Czech Republic, Estonia, Hungary, Latvia, Lithuania, Poland, Romania, Slovakia and Slovenia. In a broader sense East includes the whole post-Soviet territory.
} 
controls, where permits were issued for a limited period and could not be extended. In contrast, the UK operated a system of permanent residency permits. Other Western European countries operated a mixture of these two systems, but no country allowed an uncontrolled immigration (European Commission 2007).

In the following years, after the turmoil of the post-war migration, which was a direct consequence of the new post-Yalta world and the post-war European order, Western Europe grew up to a booming economy with a rather inelastic labour market in the 1950s and 1960s. In this period one of the common features of the West and North European countries' macroeconomic environment was excess labour demand. In particular, in the fast growing post-war West European economies (Belgium, France, Germany and Switzerland) labour markets were typically characterised by full employment and shortages of manual workers until the first oil price shock in $1973 .^{2}$ The native labour shortages were satisfied among others by the import of foreign labour force. In this period Western European countries started to actively recruit labour from their ex colonies and developing countries. As a result, due to sizable labour immigration, the structure of labour markets in Western Europe considerably changed (European Commission 2007).

\subsection{Migration in the East}

On the other side of Europe, in the former socialist countries, population movement was deemed to be a political issue and, therefore, controlled by the state government and by the Communist party. The authoritarian migration policies in the period prior to 1990 made the basic migration trends very similar across Eastern Europe. One of the common features of migration movements in the former socialist countries was the East-to-West direction, very few return migrations and hardly any international migration beyond the former Soviet bloc. ${ }^{3}$ Because of this common migration history, the East constitutes a unique migration entity, which according to $O E C D$ (2008), is a migratory pole with main migration flows between the neighbouring countries sharing common historical, economic and cultural traditions. ${ }^{4}$

More recent migration trends observed in the East reveal that the common migration behaviour from the Soviet period has radically changed in the 1990s. The transition process induced country- and region-specific political and socio-economic

\footnotetext{
${ }^{2}$ The oil crisis of 1973 was one of the main factors, which contributed to a change in migration policies in the mid-seventies.

${ }^{3} \mathrm{~A}$ notable exception was the agreement on temporary guest workers, which were hired on the basis of intergovernmental agreements between the socialist countries.

${ }^{4}$ Other authors refer to this phenomena as 'new migration space' or the 'new regional migration pole' (Kielyte and Kancs 2002).
} 
changes. These in turn contributed to growing intra-regional heterogeneity leading to more and more diverse migratory patterns within Eastern Europe. The divergence in migration behaviour across Eastern Europe was actuated by different migration policies applicable in the West for workers from the East.

With respect to migration pattern to the West we can regroup the Eastern Europe into three groups: the Baltics, the Visegrád and the Balkans. The migration behaviour is rather similar across the Baltic States (Estonia, Latvia and Lithuania) - they all are characterised by a strong outflow and a weak inflow of population. The common migration behaviour is caused by the fact that these countries shared a common history of being a constituent part of the Soviet Union from 1940 until 1990. In this period, as a result of politically forced population movements between individual republics of the former USSR, Estonia, Latvia and Lithuania observed a strongly positive migration balance. The three Baltic countries experienced large immigrant inflows before the break-up of the Soviet Union, with most of the immigrants coming from other parts of the Soviet Union. After all three Baltic countries became independent in 1991, migration patterns have reversed and migration flows turned into the opposite direction. In the first half of the 1990s, the Baltics experienced significant migration outflows, mostly of the so-called "Russian speaking" population returning to their countries of origin. In Estonia about 100000 have returned to their 'homelands', with the majority leaving to Russia. As a consequence, these countries became net emigration countries. By the end of the 1990s the emigration flows weakened considerably and migration balance became slightly positive in Estonia and Lithuania for several years.

In around the same time, the migration to the Western countries started to increase, e.g. the net emigration from Latvia to the West increased from nearly zero to 1500 in 1996. The major destinations for migrants from the Baltics were Finland and Germany for Estonia, and Israel, the US and Germany for Latvia and Lithuania. Nevertheless, with 15000 Estonians, 8000 Lithuanians and 7500 Latvians the number of the legal Baltic countries' residents living in Western countries was relatively low at the end of 1990s (Kancs and Kielyte 2002).

After the accession to the EU in 2004, the emigration from the Baltic States to the West increased substantially (Traser and Venables 2005). In all three Baltic countries the largest outflow of emigrants occurred in the years after the accession (2004-2005), when the share of emigrants increased substantially. Due to improving income possibilities in the Baltics relative to the West, it started to diminish in 2006 and 2007. The weakening of worker outflow after 2005 was also related to the domestic labour market tightening in the Baltics in 2006-2007. During this time 
Latvia, Lithuania and Estonia experienced the highest increases in wage rate among all EU member states and relatively low unemployment levels. On average, during 2002-2007 the largest gross flows of emigration were from Lithuania, followed by Latvia and Estonia. The average annual level of gross emigration was around 40 thousand people from Lithuania, 20 thousand from Latvia and 7 thousand from Estonia (European Commission 2007). As before, there were significant differences between the three countries in terms of destination countries. While the largest number of emigrants from Estonia went to Finland, followed by the UK and Ireland, the main destination country for emigrants from Latvia and Lithuania was the UK, followed by Ireland and Germany. Furthermore, while the annual emigration to most of the countries fluctuated in different years, it was relatively stable to Germany. In addition, the cross country differences are notable. Whereas the emigration flows increased fourfold from Lithuania and Latvia after the EU enlargement (compared to 2002-2003), they only doubled from Estonia.

European Commission (2010) suggest that in 2009, twenty years since the fall of the Wall, the highest worker mobility rate among all EU member states was in Lithuania, with around $3 \%$ of total population having moved to other EU member states since the EU enlargement.

Migration pattern in the Visegrád is rather different. Before the EU enlargement, nearly 300 thousand persons from the Visegrád were legally employed in the EU, accounting for $0.2 \%$ of the EU workforce (or around $6 \%$ of total non-EU foreign workers (European Commission 2007). Germany and Austria hosted $70 \%$ of Visegrád workers in the EU. Broken down by sending country, 55000 were from Bulgaria, 35000 from the Czech Republic, 20000 from Slovakia, 77000 from Hungary, 435000 from Poland, 155000 from Romania, and 20000 from Slovenia. As a result of closed labour markets but unrestricted travel, it was estimated that, in addition to legal workers, there were around 600000 undocumented workers from the Visegrád countries. The total number of legal immigrants, both working and non-active persons, from the Visegrád was approximately 830000 in the beginning of 2000s (European Commission 2007).

Simultaneously to outflows to the West, the Visegrád itself developed into a migrant-receiving area. The Czech Republic, a regional leader, hosted as many as 150000 migrant workers or foreign entrepreneurs in 2002, the majority of whom came from Slovakia and Ukraine. Also Hungary and Slovenia (and to lesser extent Poland) received substantial numbers of immigrants. Most of the countries recorded also large inflows of asylum seekers; e.g. between 1996 and 2003 the Czech Republic 63000, Hungary 45000, Poland 35000 and Slovakia 33000 (European Commission 2008). 
The emigration to the West increased substantially after the enlargement in 2004. In 2004 the number of the residents from these countries stood at around 900000. Although, the exact scale of post-enlargement migration flows are difficult to determine, population statistics and Eurostat's LFS survey data suggest that the total number of people from the Visegrád, living in Western Europe has increased by around 1.1 million since the enlargement in 2004 (European Commission 2010). Ireland has been by far the largest receiving country in the Visegrád relative to its population size, with around $5 \%$ of its current working age population from the Visegrád, followed by the UK (1.2\%). Also Austria and Luxembourg host significant proportions of the recent arrivals from the Visegrád, albeit much fewer than in the UK and Ireland. In all other Western receiving countries the population share of the recent Visegrád arrivals is very small, even in Sweden, which never applied restrictions to the free movement of workers, and in those MS, which have opened their labour markets since 2006.

As already noted, the mobility of labour force is different across the Visegrád countries. Polish citizens accounted for $25 \%$ of all recent intra-EU movers, who changed their residence to another EU member state. Around $60 \%$ of Poles went to the UK, while the second destination was Ireland. In total, around $2 \%$ of total Polish and Slovak population have moved to other EU member states since the EU enlargement in 2004. On the other hand, the Czech Republic and Hungary showed rather low mobility rates, which are similar to those of West.

As noted by European Commission (2007), Balkans embodies one of the most complicated migration and refugee issues in the entire world. According to the estimates by Parsons et al (2005), over 10 million persons - out of a total population of some 80 million in the Balkan Peninsula - have moved between 1990 and 2000. Only 2.5 million persons returned to their homes, about 5 millions have emigrated permanently to other European or oversees countries, and about 3 million are still in a kind "stand-by" situation, waiting to make the final decision to stay permanently or to return. This implies that about $15 \%$ of the population has been on the move since the political changes at the end 1980s, which is very high percentage by international standards. These sizeable population movements in the Balkans may have severe implications for economic development, welfare and security in the whole Europe.

\section{Conceptual framework}

Innovative capital in general and human capital in particular takes a central role in most theories of economic growth and development. Both the augmented neo- 
classical growth models (Solow 1956; Mankiw et al 1992) and endogenous growth models (Lucas 1988; Romer 1990) stress the importance of innovative capital in economic development in one way or another. For reasons explained below, we rely on the Romer's (1990) model.

\subsection{Endogenous growth}

The endogenous growth model of Romer (1990) has three sectors: a technology producing sector, an intermediate goods producing sector where capital goods are produced, and a final output producing sector. The production function is given by

$$
Q=L_{H \gamma}^{a} L_{U}^{\beta} \int_{0}^{I} x_{i}^{1-\alpha-\beta} d i
$$

where $L_{H \gamma}$ is the share of human capital employed in the production sector, which depends on the overall stock of human capital $L_{H T}=L_{H \gamma}+L_{H}$, with the latter denoting the share of human capital devoted to the accumulation of technology, $I$. The part of human capital that is not used for producing goods and services, $L_{H}$, is used for creating new technologies. The level of human capital, $L_{H}$, has thus a positive effect on the growth of technology, $I$, the level of which determines the number of differentiated intermediate goods, $x$.

The innovation sector operates according to a national innovation production function:

$$
\dot{I}=\delta L_{H}^{\alpha_{1}} K^{\alpha_{2}}
$$

where $\dot{I}$ is a sustainable rate of innovation and $\delta$ is a productivity parameter. According to equation (2), the sustainable rate of innovation, $\dot{I}$, is an increasing function of the number of skilled workers, $L_{H}$, and the stock of knowledge available to these skilled workers, $K$. The two coefficients $\left(\alpha_{1}\right.$ and $\left.\alpha_{2}\right)$ measure the relative contribution of the two innovative inputs: human capital and knowledge capital. Parameter $\alpha_{1}$ determines whether the marginal product of an additional invention is increasing (the so-called 'standing on shoulders' effect, Caballero and Jaffe 1993) or decreasing (the so-called 'fishing out' hypothesis) in the stock of human capital, and parameter $\alpha_{2}$ determines the returns to scale with respect to the stock of existing knowledge. $\delta$ is a productivity parameter, which captures all other factors affecting the creation of innovative capital but not captured by variables $L_{H}$ and $K$.

Romer's (1990) model is particularly attractive for our study for two reasons. First, the rate of technological change is endogenous because the share of the economy 
devoted to the innovation sector is a function of the skilled workforce (determining $L_{H}$ ), and the allocation of resources to innovative activities depends on the $\mathrm{R} \& \mathrm{D}$ productivity. Second, the rate of technological change is endogenous because the productivity of innovation creation is sensitive to the stock of knowledge capital, $K$, created by past innovations. Although, there is neither a general agreement on the precise values of these parameters nor on the functional form linking innovations to economy-wide long-term productivity growth, there is a relatively broad agreement that these factors are, indeed, crucial in explaining the realised level of economy-wide innovation (Furman at al 2002).

\subsection{Determinants of growth: the innovative capital}

Applying a logarithmic transformation to equation (2) and rewriting the growth rate in form of stock changes we obtain innovation production for a closed economy:

$$
\ln I=\delta+\alpha_{1} \ln L_{H}+\alpha_{2} \ln K
$$

According to equation (3), the national innovative output, $I$, is an increasing function of the size of skilled workforce, $L_{H}$, and the stock of knowledge available to workers, $K$. Given that both innovative inputs $\left(L_{H}\right.$ and $\left.K\right)$ are accumulable, their endowment is determined endogenously in the model. The size of the human capital, $L_{H}$, is determined by the size of educated work force, $L_{H}$, and the size of knowledge capital, $K$, depends on national R\&D.

In open economies with international flows of knowledge and human capital, the national innovative capital depends not only on country's endowment with skilled workers and technology, but also on the net migration of skilled labour (Sjaastad 1962; Bhagwati and Rodriguez 1975) and international knowledge spillovers (Krugman 1979). Not accounting for skilled labour emigration would underestimate the return to education (human capital), whereas not accounting for international knowledge spillovers would underestimate the marginal revenue of national $R \& D$ expenditure (knowledge capital). Therefore, we introduce high-skill migration and international knowledge flows into equation (3), which yields: 


$$
\begin{aligned}
& \ln I^{S}=\ln \delta^{S}+\alpha_{1} \overbrace{\text { worker }}^{\ln \left(L_{H}^{S}\right.}+\overbrace{\text { high-skill }}^{\left.L_{H}^{m}\right)}+\overbrace{\text { domestic }}^{\alpha_{2} \ln (K^{S}+\overbrace{\text { knowledge }}^{m})} \\
& \underbrace{\text { education migration }} \underbrace{\text { innovation spillover }} \\
& \text { human capital knowledge capital }
\end{aligned}
$$

According to equation (4), open economy $S$ 's innovative output, $I^{S}$, depends on the size of skilled workforce, $L_{H}^{S}$, net migration of skilled workers, $L_{H}^{m}$, domestic knowledge production through $\mathrm{R} \& \mathrm{D}, K^{S}$, inward knowledge spillover, $K^{m}$, and parameters of the model..$^{5}$ The relative contribution of the four components to national innovative supply, $I^{S}$, depends on the equilibrium strategies of economic actors.

\subsection{Human capital}

Assume that sending country $S$ is endowed with $L^{S}\left(=L_{H}^{S}+L_{U}^{S}\right)$ units of labour, which is shown on the horizontal axis in the left panel of Figure 1. Skilled labour, $L_{H}^{S}$, is measured from the left to right, whereas unskilled labour, $L_{U}^{S}$, from the right to the left. Curves $D_{H}^{S}$ and $D_{U}^{S}$ represent the demand for skilled and unskilled labour, respectively, and $S_{H}^{S}$ is the supply of skilled labour in $S$.

According to equation (4), workers decide on two issues: education and migration. ${ }^{6}$ First, we consider the education decision in autarky, where workers choose between offering unskilled labour versus investing in education and offering skilled labour. According to Averett and Burton (1996), the education decision is determined by a trade-off between skill premium (difference between skilled wage, $w_{H}^{S}$, and unskilled wage, $w_{U}^{S}$ ), the cost of education, $E C^{S}$, and the stock of knowledge, $K^{S}$. Thus, in equation (5) we explicitly assume that education is costly for workers. These costs capture both direct costs of education, such as tuition fees, as well as indirect costs, such as worker opportunity costs and education effort (which is different across individuals).

$$
L_{H}^{S}=L_{H}^{S}\left(w_{U}^{S}, w_{H}^{S}, E C^{S}, K^{S}\right)
$$

\footnotetext{
${ }^{5}$ For the sake of simplicity, we assume that national knowledge spillovers, $K^{S}$, are already accounted for in the domestic knowledge production function, $K^{S}$. The LDC sending country is denoted with superscript $S$ and the EU receiving country with superscript $R$.

${ }^{6}$ We recognise that in reality there are many more decisions to make, e.g. labour-leisure, consumption, etc.
} 
Given that education is costly, workers invest in education only if education increases their net income. ${ }^{7}$ Thus, net of education costs, workers must earn at least the unskilled labour wage, which is equal to $w_{U}^{S *}$. The vertical difference between skilled labour supply, $S_{H}^{S}$, and unskilled wage rate, $w_{U}^{S *}$, represents the cost of acquiring education (Figure 1, left panel). It's slope is increasing because workers are not equally talented, they are heterogeneous in their ability to acquire education (Cameron and Heckman 1998). In line with Willis and Rosen (1979), the last skilled worker, who enters education at $L_{H}^{S *}$, is just able to compensate the education costs, his skill premium is equal to zero. Assuming full employment, the rest of workers, $L^{S}-L_{H}^{S}$, stay unskilled. The equilibrium wage of unskilled workers without migration, $w_{U}^{S *}$, is at the point where the demand for unskilled labour, $D_{U}^{S}$, intersects vertical line at $L_{H}^{S *}$. The equilibrium stock of skilled labour is $L_{H}^{S *}$ and skilled labour wage rate is $w_{H}^{S *}$. In equilibrium the education cost of the marginal worker, who enters education, is equal to $E C^{*} .8$

The equilibrium for receiving country, $R$, is analogous. In absence of migration, the equilibrium skilled wage, unskilled wage and the stock of skilled labour are $w_{H}^{R *}$, $w_{U}^{R *}$, and $L_{H}^{R *}$, respectively (Figure 1, right panel).

Second, we consider the skilled worker decision where to offer their work, at home or abroad, which determines the short-run equilibrium migration. According to Sjaastad (1962), the trade-off, which workers face here, is given by the expected income increase through migration versus migration costs, MC, (equation 6). ${ }^{9}$ Workers migrate if the expected benefits arising from migration are higher than migration costs. ${ }^{10}$

$$
L_{H}^{m}=L_{H}^{m}\left(w_{H}^{S}, w_{H}^{R}, M C\right)
$$

where $L_{H}^{m}$ is skilled labour migration, $w_{H}^{R}$ is skilled wage rate in $R$, and $M C$ are migration costs.

\footnotetext{
${ }^{7}$ We implicitly assume that all workers, for whom it pays off to become skilled, invest in education.

${ }^{8}$ For the sake of graphical tractability, we assume that the elasticity of unskilled labour demand is infinitely elastic. If the elasticity of unskilled labour demand would be partially elastic, then there would be additional unskilled labour wage effect, which would affect the ratio of skilled/unskilled workers in $S$. However, the obtained results with partially elastic unskilled labour demand would be qualitatively similar to those presented above.

${ }^{9}$ These costs include not only the direct transportation costs to the destination country, but also employment uncertainty (which is higher abroad than at home), social costs of leaving family and/or friends behind, cultural adjustment costs, language barriers etc (Straubhaar 1986).

${ }^{10}$ We recognise that in reality the migration decision of workers is driven not only by wage differences but also by non-economic considerations. However, in the present study we abstract from all other determinants of migration and consider cross-country wages differences as the only force driving labour migration.
} 
Due to cross-country differences in knowledge capital, $K^{R}>K^{S}$, the receiving country, $R$, is more developed than sending country, $S$. Differences in country development and hence wage levels trigger migration from $S$ to $R$. In presence of positive migration costs, $M C>0$, the net wage, which migrant workers earn, is lower than skilled incumbent wage in $R$, because the net wage of migrants is skilled wage in destination country, $w_{H}^{R}$, minus migration costs, $M C$.

According to migration network theory and the empirical evidence (Carrington, Detriagiache and Vishwanath 1996), migration costs are not constant, they decrease in the number of migrants from $S$ residing in $R$. In Figure 1 (middle panel) these network effects are captured by a decreasing distance between curves $S_{M C}^{m}$ and $S^{m}$. Curve $S^{m}$ is migrant work supply on the international labour market, which is derived by subtracting skilled labour supply, $S_{H}^{S}$, from skilled labour demand, $D_{H}^{S}$, in $S$. Curve $S_{M C}^{m}$ is migrant supply adjusted by migration costs $M C$.

In equilibrium $L_{H}^{m}$ skilled workers migrate incurring migration cost, $M C^{*}$, and receiving net wage, $w_{H}^{m}\left(=w_{H o}^{R *}-M C^{*}\right)$. The equilibrium wage rate of skilled labour, $w_{H o}^{R *}$, is determined by the intersection of migration supply, $S_{M C}^{m}$, and migration demand $D^{m}$ (Figure 1, middle panel). Migration demand, $D^{m}$, is derived by subtracting skilled labour demand, $D_{H}^{R}$, from supply, $S_{H}^{R}$ (right panel in Figure 1). Immigration reduces skilled wage in $R$ from $w_{H}^{R *}$ (skilled equilibrium wage without migration) to $w_{H o}^{R *}$ (skilled equilibrium wage with migration). The magnitude of the wage effect depends on the sending country $S$ 's relative size - the larger is $S$ relative to $R$, the bigger is the wage effect in $R$. If $S$ is sufficiently small, then migration does not affect wage rate in $R$ at all. This would be the case if $S$ faces perfectly elastic skilled labour demand in $R$, such as $D_{H 1}^{R}$ (Figure 1, right panel). In this case skilled labour wage in $R$ would be equal to $w_{H o}^{R *}$ both with and without migration and migration would be equal to $L_{H}^{m}$.

Workers from $S$ migrate to $R$ as long as $w_{H}^{R *}-M C^{*}>w_{H}^{S *}$. The mass of skilled workers that emigrate, $L_{H}^{S m}-L_{H}^{S n}$, is determined by slope of migrant work supply curve, $S_{M C}^{m}$. Due to emigration, the stock of skilled and unskilled labour in $S$ decreases from $L_{H}^{S *}$ to $L_{H o}^{S n}$, and from $L^{S}-L_{H}^{S *}$ to $L^{S}-L_{H}^{S m}$, respectively. Given that the stock of skilled workers decreases relatively more than that of unskilled, the return to education increases. As a result, the equilibrium mass of workers who acquire education increases from $L_{H}^{S *}$ to $L_{H o}^{S m}$, with $L_{H}^{S *}<L_{H o}^{S m}$.

In Figure 1 we assumed that only skilled workers have a migration option. Abstracting from unskilled worker migration is motivated by two considerations: focus of the study and empirical evidence (Salt 1997). Moreover, it can be easily verified that, as long as the condition $L_{H}^{S} / L_{U}^{S} \leq L_{H}^{m} / L_{U}^{m}$ holds, the results with unskilled 
labour migration would be qualitatively equal to those presented here.

\subsection{Knowledge capital}

According to equation (4), the level of knowledge available in $S$ is determined by domestic knowledge production and foreign knowledge spillovers. Knowledge creation involves production of new knowledge, whereas knowledge adoption is uptake of knowledge developed in other countries (both are costly). In order to increase the level of knowledge, sending country, $S$, can invest in knowledge production (new knowledge) or in knowledge adoption of inward spillovers (adopted knowledge).

In equation (7) the level of technology (knowledge) available in $S$ is determined by a total (private and public) expenditure on knowledge, $T R^{S}$, and skilled workforce, $L_{H}^{S}$. Knowledge, $K^{S}$, increases in both R\&D expenditure, $T R^{S}$, and human capital, $L_{H}^{S}$, which increases the productivity of knowledge. ${ }^{11}$

$$
K^{S}=K^{S}\left(T R^{S}, L_{H}^{S}\right)
$$

In absence of knowledge flows between countries (autarky), the only source of country $S$ 's knowledge improvement is innovation through investment in R\&D. The autarky equilibrium knowledge in $S$ is shown upper panel of Figure 2, where horizontal axis measures the level of knowledge, $K^{S}$, and vertical axes measures units of expenditure spent on knowledge accumulation, $\operatorname{tr}^{S}\left(=T R^{S} / K^{S}\right)$. We assume that marginal costs of knowledge creation, $M C_{C}^{S}$, are increasing in technological development, and marginal productivity (benefit) of knowledge demand, $M B^{S}$, is decreasing in technological development (both new and adopted knowledge). This is represented by upward and downward sloping marginal cost and productivity curves, $M C^{S}$, and $M B^{S}$, respectively (upper panel in Figure 2). In absence of international knowledge flows, the equilibrium domestic innovation, $K_{C}^{S *}$, is at the point where marginal costs of knowledge creation, $M C_{C}^{S}$, equal marginal productivity of knowledge, $M B^{S}$. Equilibrium innovation, $K_{C}^{S *}$, implies $t r^{S *}$ units of R\&D expenditure.

Analogously, knowledge for receiving country, $R$, is shown in bottom panel of Figure 2 . The intersection between receiving country, $R$ 's, marginal cost of knowledge creation, $M C_{C}^{R}$, and marginal productivity of knowledge, $M B^{R}$, yields equilibrium domestic innovation and per unit expenditure $K_{C}^{R *}$ and $t r^{R *}$, respectively.

Next, consider the opening of borders for international knowledge flows. Assuming higher skilled/unskilled labour force ratio in $R$ implies higher equilibrium knowledge in $R$ than in $S,\left(K_{C}^{R *}>K_{C}^{S *}\right)$. As shown in Figure 2, in open economy equilibrium

\footnotetext{
${ }^{11}$ This follows from equation (2).
} 
more knowledge available in $R$ allows $S$ to adopt inward knowledge spillovers from the more developed $R$. The maximum level of spillover knowledge which can be adopted in $S$ is equal to $R$ 's equilibrium knowledge production, $K_{C}^{R *}$. On the other hand, in a two country model $R$ cannot benefit from knowledge spillovers from $S$, because the technological development in $S$ is lower than in $R$.

We assume that $S$ 's marginal costs of knowledge adoption are constant, given along the horizontal line $M C_{A}^{S}$, which implies that in absence of knowledge flows between countries, the equilibrium expenditure of knowledge creation, $\operatorname{tr}^{R *}$, is higher than the marginal costs of knowledge adoption, $M C_{A}^{S}<t r^{R *}$ in equilibrium. ${ }^{12,13}$ This assures that in presence of knowledge flows between countries knowledge adoption may yield positive profits. The total equilibrium knowledge in $S$ is $K_{T}^{m}$, which is a sum of domestically created knowledge, $K_{C}^{m}$, and the adopted foreign knowledge, $K_{A}^{m}\left(=K_{T}^{m}-K_{C}^{m}\right)$. Hence, in presence of international knowledge spillovers the equilibrium knowledge production is lower in $S, K_{C}^{m}<K_{C}^{S *}$ (though the total knowledge in $S$ is higher, $K_{T}^{m}>K_{C}^{S *}$ ). Note that knowledge equilibrium in $R$ is not affected by international spillovers, because due to country development gap knowledge spillovers are one-directional: from the more developed receiving country, $R$, to the less developed sending country, $S$.

\section{Migration's impact on education}

According to Borjas (2001), skilled emigration affects the sending country's education level through several channels. ${ }^{14}$ First, skilled worker emigration induces shifts in the relative factor endowment, which in turn exerts upward pressure on skilled wages. As a result, increased skilled/unskilled wage ratio in the sending country increases the long run education equilibrium. On the other hand, skill downgrading in the receiving country, which often is referred to as brain waste, reduces education equilibrium at

\footnotetext{
${ }^{12}$ Note that we assume differences in marginal costs between knowledge creation and knowledge adoption. This is consistent with the finding in the literature. According to Mansfield (1981), on average imitation costs are about 65 percent of the original innovation costs. Further, we assume that both new and adopted knowledge are homogenous in production, i.e. they do not differ with respect to marginal productivities.

${ }^{13}$ In reality the marginal costs of knowledge adoption may increase with additional knowledge adopted. However the slope of the marginal costs of knowledge adoption should be lower than the marginal costs of knowledge creation (Mansfield 1981). To simply the figures we assume constant marginal costs of knowledge adoption, but the results hold in general.

${ }^{14}$ In the short run migration may also increase due to the so called 'migration ticket' effect. Several recent studies (e.g. Docquier and Rapoport 2004) find that migration prospects foster domestic enrolment in education as it increases the probability of finding a job abroad and hence the expected (average) return to investment in education. Kancs and Ciaian (2007) label the phenomenon of investing in education at home for migration purposes as 'migration ticket price'.
} 
home.

The empirical evidence for migration's impact on the sending country wages can be found in several historical migration episodes. For instance, manufacturing wages in Slovakia have tracked recruitment of overseas workers remarkably closely, despite persistent, high unemployment rates. In the Baltic countries, wages for both skilled and less skilled workers, particularly in the construction sector, have responded over time to the mass movements of men to Scandinavia and British Islands (Kielyte and Kancs 2002). For receiving countries the opinions are divided. Borjas (1999, 2003, 2005) find that immigration, high and low skilled, decreases native wages and employment in host countries. In contrast, Borjas et al. (1996), Filer (1992), Butcher and Card (1991), Card (2005, 2001), Hunt (1992) point out that the effects should not be over-rated and wage effects in the Eastern sending countries would be moderate at most.

The second effect is skill downgrading in the receiving country, which is often referred to as 'brain waste'. The downgrading of migrant work in the destination countries affects the education decision of unskilled workers in home countries. Because the majority of skilled migrants are employed in unskilled jobs abroad, a reduced skill premium reduces incentives for unskilled workers to enter education and acquire skills in the sending country. Note that not only the potential migrants are affected but, through lower international wage for migrant labour, also workers staying in the sending countries are affected. Thus, theoretically, the foreign wage signal will decrease the equilibrium education in the sending country.

According to empirical evidence from West European and North American destination countries, only a small part of highly skilled immigrants are employed in skilled jobs (Mattoo et al. 2005, Drinkwater et al. 2006). ${ }^{15}$ Usually, the majority of skilled migrants from the East work in sectors requiring little qualification, such as agriculture, transport or construction. For example, data from the US and Swiss censuses show that, because of labour segmentation in destination countries, only

\footnotetext{
${ }^{15}$ There are several explanations why many of highly skilled East European migrants working abroad are occupied in low-skilled jobs, where their professional qualifications are not appropriately employed. It can be explained by certain country attributes, which affect the quality of human capital accumulated at home, including the use of English as a medium of education. First, the lack of harmonisation between the educational systems within Europe implies that university diplomas from Eastern Europe often are not recognised in Western Europe. Second, in many post-Soviet transition countries the mostly public-financed tertiary education sector produces graduates with countryspecific skills rather than the internationally-applicable qualifications (Poutvaara 2008). Third, the imperfections of labour markets in receiving countries, especially the administrative barriers created to protect the native workers, make skilled employment for foreigners very difficult, if not impossible. As a result, skilled immigrants from Eastern Europe receive, to a large extent, very low returns on their human capital (brain waste).
} 
about one third of skilled migrants with tertiary education from the Balkan countries have obtained skilled jobs (Lucas 2004). According to Table 1, this effect seems to be particularly pronounced for workers from the East.

Table 1 reports the occupational outcomes of immigrants, particularly of highly educated and those with professional qualifications. The reported figures suggest striking differences in the occupational attainment of immigrants from different countries with similar educational backgrounds, and show that from some East European countries only around one third of skilled migrants work in skilled jobs. Even after controlling for age, experience and education level, highly educated immigrants from certain countries are less likely to obtain skilled jobs. For example, a hypothetical 35 years old Polish college graduate who arrived in 1994, has only $35 \%$ probability of obtaining a skilled job while the probability is $59 \%$ for a Latvian immigrant of identical age, experience and education (Mattoo et al. 2005).

Table 1: Probability of obtaining skilled jobs - different cohorts and education levels

\begin{tabular}{lccccc}
\hline \hline Education Level & $1970 \mathrm{~s}$ BS & 1980s BS & 1990s BS & 1990s MS & 1990s PR \\
\hline Bulgaria & 0.00 & 0.27 & 0.37 & 0.56 & 0.65 \\
Czech\&Slovak & 0.41 & 0.32 & 0.34 & 0.52 & 0.42 \\
Hungary & 0.60 & 0.37 & 0.55 & 0.68 & 0.87 \\
Latvia & 0.30 & 0.50 & 0.59 & 0.73 & 0.87 \\
Lithuania & 0.80 & 0.61 & 0.31 & 0.50 & 0.40 \\
Moldova & 0.17 & 0.00 & 0.49 & 0.65 & 0.56 \\
Poland & 0.35 & 0.25 & 0.35 & 0.55 & 0.65 \\
Romania & 0.40 & 0.41 & 0.40 & 0.59 & 0.70 \\
Russia & 0.49 & 0.41 & 0.45 & 0.63 & 0.61 \\
Ukraine & 0.29 & 0.46 & 0.39 & 0.58 & 0.62 \\
Yugoslavia & 0.31 & 0.21 & 0.29 & 0.49 & 0.59 \\
\hline \hline
\end{tabular}

Source: Mattoo et al. 2005, based on US Census 2000 data. Notes: BS - Bachelors degree, MS - Masters degree, and PR - Professional education. $1=\max (100$ percent probability), $0=\min (0$ percent probability).

The third effect arises because of worker ability heterogeneity. It is well known that not all people are equally talented. For example, they are heterogeneous in their ability to acquire education (Patrinos and Sakellariou 2006, Schiff 2005). The lifetime utility maximisation of workers implies that, in the presence of positive costs of education, only the most talented obtain education. This in turn implies that, on average, those workers which were unskilled before emigration of highly skilled are less talented than those who have first obtained education. Because of worker heterogeneity in terms of their abilities and positive selection of migrants, acquiring 
skills through education will be more costly for the remaining unskilled workers. I.e. their wage increase (which is lower due to lower marginal productivity) net of schooling costs and effort are lower compared to skilled talents, who emigrated. As a result, after emigration of the most talented workers (who first became educated), home country will have less skilled workers in equilibrium than it would have if all workers were equally talented and able.

Borjas (1987) provides empirical evidence that migrant workers differ from nonmigrants along several dimensions. Usually, migrants are positively selected, i.e. they are younger, better educated and more skilled. Docquier and Marfouk (2006) report that the selection rates (rates of highly skilled compared to total migrants) in 2000 among emigrants were the highest in Croatia (29.4\%), Bosnia and Herzegovina (28.6\%), Albania (20.0\%), Serbia and Montenegro (17.4\%), Slovakia (15.3\%), Romania (14.1\%), Estonia (13.9\%), Poland (12.3\%), Hungary (12.1\%), Lithuania (11.8\%) and Latvia (10.2\%). Only in the Czech Republic it was below $10 \%$ of emigrants. ${ }^{16}$

The fourth effect is associated with remittances, as they affect education decision of liquidity constrained unskilled workers. Highly skilled workers, as other groups of migrants, tend to remit part of their income received abroad to their families in the home country. According to Cox (1987), skilled worker remittances differ from unskilled worker remittances in at least two respects: quality and quantity. On the one hand, highly-skilled migrants remit less than unskilled because skilled migrants are more likely to settle and to reunite with their family in the receiving country. However, highly skilled earn more on average than low-skilled, and empirical data show that the likelihood of remitting and the amount remitted, increase with emigrant earnings (Lowell and Findlay 2001). Furthermore, in contrast to unskilled worker remittances, which mostly are spent for consumption goods, the remittances of skilled migrants are more often directed towards investment in fixed assets (e.g. housing) and education (World Bank 2000). In addition, remittances from the skilled emigrants can also provide incentives for human capital accumulation among members of recipient households since they validate the increased rewards with education and migration. If invested in education, remittances may move upward or completely remove the liquidity constraint of education. As a result, more workers, particularly those restrained from education by a liquidity constraint (which is often the case in

\footnotetext{
${ }^{16}$ In order to quantify international high skill migration, Docquier and Marfouk (2006) calculate a selection indicator, which is given by the proportion of skilled (defined as migrants with tertiary education) emigrants in the total emigration stock.
} 
poor sending countries), ${ }^{17}$ are able to acquire skills through education. ${ }^{18}$

Table 2: The share of remittances in GDP in 2006-2008

\begin{tabular}{lrrr}
\hline \hline & 2006 & 2007 & 2008 \\
\hline Albania & 27.3 & 26.1 & 25.0 \\
Bosnia and Herzegovina & 24.0 & 22.2 & 20.7 \\
Bulgaria & 8.8 & 8.1 & 8.1 \\
Croatia & 12.0 & 11.5 & 11.1 \\
Czech Republic & 3.9 & 3.9 & 3.8 \\
Estonia & 4.9 & 4.6 & 4.4 \\
Hungary & 4.8 & 4.7 & 4.8 \\
Latvia & 6.1 & 5.7 & 5.5 \\
Lithuania & 5.7 & 5.4 & 5.0 \\
Macedonia & 21.4 & 20.7 & 20.0 \\
Moldova & 35.3 & 33.3 & 31.6 \\
Montenegro & 19.4 & 17.1 & 14.6 \\
Poland & 5.9 & 5.8 & 5.7 \\
Romania & 8.6 & 7.9 & 7.3 \\
Serbia & 18.8 & 18.2 & 18.2 \\
Slovakia & 5.0 & 4.7 & 4.5 \\
Turkey & 15.0 & 14.0 & 13.6 \\
\hline \hline
\end{tabular}

Source: IMF Balance of Payments Statistics (2009) and National Statistics.

The empirical evidence of remittances in Eastern European is provided in Table 2. According to the IMF (2009) estimates and National Statistics, income received from friends and relatives abroad as a proportion of the national income (GDP) are particularly high in Moldova (35.3-31.6\%), Albania (27.3-25.0\%), and Bosnia and Herzegovina (24.0\%-20.7\%). These countries are among the world's largest recipients of remittances as a portion of GDP. However, also in other Southeast European countries remittances are significant (Macedonia, Montenegro, Serbia). In addition, there is plenty of evidence that official remittance figures tend to underestimate the actual flows as part of the transfers between migrants and their families occurs through

\footnotetext{
${ }^{17}$ Lowell and Findlay (2001) suggest that there might be an optimal level of emigration that stimulates the pursuit of higher education in the sending countries and spurs economic growth.

${ }^{18}$ According to World Bank (2000), especially for poor families in less developed economies remittances often help to cope with liquidity constraints locking the access to formal education. World Bank (2000) reports in its study that about $80 \%$ of remittances transferred to Albania went to poor households. In more developed economies educational remittances provide access to a better education and training either at home or abroad. In both cases the remittance investment in education leads to more educated workforce and/or a better (higher quality) education resulting in more human capital.
} 
informal networks. ${ }^{19}$ More generally, Ledesma and Piracha (2001) and Lucas (2004) find that remittances lead to a positive effect on economic growth, whether through increased education, consumption, savings or investment and have important multiplier effects.

\section{Migration's impact on cross-country distribution of skilled labour force}

In this section we examine the long-run effects of high skill migration on determinants of migration as, according to previous studies (e.g. Borjas 2001), current migration affects the migration decision of potential migrants in future. For example, through changes in relative wages in home and host countries, changes in migration cost. ${ }^{20}$ As usual, we assume that migration decision is determined by a trade-off between expected increase in earnings and migration cost.

The direct and the most visible effect of high skill emigration on human capital stock in sending country - the direct brain drain effect - is transfer of human capital embodied in labour (Bhagwati and Hamada 1974). ${ }^{21}$ Given that skilled migrants transfer the entire human capital embodied in their private productive skills, the stock of human capital in the sending country is declining proportionally to the number of emigrating skilled workers. High levels of skill emigration (leading to the so called "brain drain") have adverse effects on growth and development in sending countries, as it reduces one of the key growth determinants - the stock of human capital - and unfavourably affect those who remain (Lowell and Findlay 2001).

In the medium to long run, skilled worker migration affects also wages in home and host countries and migration costs, which in turn affect the migration decision itself. As noted above, skill emigration leads to reduced skill supply in the sending country. If the demand for labour does not change (which is more likely to hold in short-run than in long-run), a decreasing labour supply will exert an upward pressure on wages in sending country. Rising wages in sending country will narrow the migration-driving

\footnotetext{
${ }^{19}$ A World Bank (2006) survey indicates that between one-third and two-thirds of migrants, depending on their country of origin, tend to use informal channels to transmit remittances.

${ }^{20}$ In reality, there are many more forces at work. For example, the economic geography and urban systems literature stress that because of agglomeration economies, firms in the larger region will be able to pay higher wages attracting in such a way even more workers. However, for the purpose of the present study, we abstract from these effects, as we think that at international scale they are less pronounced.

${ }^{21}$ Given that the human capital embodied in skilled workers is draining out of country, in the migration literature this effect is often referred to as a 'brain drain'. A brain drain can occur when emigration of tertiary educated persons reaches significant levels and is not offset by other "feedback" effects (Lowell and Findlay 2001).
} 
wage gap between source and destination countries, reducing migration in the next period (Borjas 1994). Thus, theoretically, wage flexibility in the source country has a positive impact on human capital stock. ${ }^{22}$

As noted in section 4, the empirical evidence suggests that emigration increases wages in the sending countries. For example, according to Kielyte and Kancs (2002), in Baltic countries emigration first helped to reduce labour market pressures in the time of rapid economic changes and structural adjustments, decreasing in such way unemployment. In the recent years - after the latest EU enlargements - emigration led to labour shortages in some fast growing CEE economies (such as Baltic States), which in turn exerted upward pressure on wages which increased by $20-30 \%$ annually exceeding productivity growth by far. However, it has to be noted that even here emigration only reinforced the tight labour market situation, as high economic growth was the primary source of labour shortages.

According to Borjas (1994), international labour migration affects not only wage rate in the sending country but also in the destination country. The immigration of workers increases labour supply in the destination country which, in turn, exerts a downward pressure on wages. Lower wages in the destination country narrow the migration-driving wage gap between the sending and receiving countries. Smaller wage differences in turn attract fewer migrants. Less emigrating skilled workers imply higher human capital stock in the sending country. Thus, theoretically, wage flexibility in the destination country also has a positive impact on human capital stock in the sending country. However, the destination country's wage effect depends on the relative size of countries. The larger is the sending country relative to the receiving country, the larger is wage effect and vice versa.

Several studies have empirically assessed the impact of migration on wages in a number of West European receiving countries. Table 2 summarises the key findings of selected empirical studies on migration's impact on wages. Most of these studies rely either on a cross-section of regions or branches and use variations in migrant density in order to identify the impact of migration on wages and employment. One approach estimates a traditional wage equation, where wage is explained by a vector of human capital characteristics, macro variables, which should control for regional demand shocks, and a measure for the density of migrants. Another branch of literature (Grossman 1982), estimates the elasticity of substitution of different types of labour in the production function. Both approaches rely on the assumption that changes in

\footnotetext{
${ }^{22}$ However, we acknowledge that it might be a too simplistic conclusion as wages in the sending country have to increase in line with productivity growth. If that is not the case excessive wage increases would lead to increasing price pressures and other possible imbalances in economic growth such as e.g. overheating of the economy.
} 
the proportion of factors through migration involve changes in the price/income of the respective factor. ${ }^{23}$

Table 3: Studies on the impact of migration on wages in the destination country

\begin{tabular}{lcccc}
\hline \hline Study & Country & Approach & Control & Elasticity \\
\hline DZ & Germany & Wage equation & IV & 1.4 \\
HDZ & Germany & Wage equation & IV & 1.3 \\
B & Germany & Production function & IV & 0.1 \\
GVV & Italy & Wage equation & FD & 0.1 \\
BKS & Germany & Wage equation & IV & -0.1 \\
HH & Austria & Wage equation & IV & 0.1 \\
\hline \hline
\end{tabular}

Notes: DZ - DeNew and Zimmermann (1994) based on Household panel (GSOEP, 1982-89), HDZ - Haisken, DeNew and Zimmermann (1995) based on Household panel (GSOEP, 1982-89), B - Bauer (1997) based on Cross-section, IAB-employment, (1990), GVV - Gavasto, Venturini and Villosio (1999) based on Panel, Social security archive (SAA), BKS - Bruecker, Kreyenfeld and Schraepler (2001) based on IAB-employment sample (1990-95), Hofer and Huber (2001) based Social security records.

The last column reports the elasticity between percentage change in wages and increase in the proportion of foreign citizens of one percentage point, which is equal to an increase in employment through migration by one percent. ${ }^{24}$ The elasticities reported in Table 2 suggest that a one per cent increase in the labour force through migration yields a change in native wages in a range between minus 0.1 and plus 1.4 percent. Most of these studies find an upward shift of native wages less than one percent. Blanchflower et al. (2007), Gilpin et al. (2006), Wadensjö (2006) have analysed the impact of post-accession inflows of CEE workers into the UK, Ireland and Sweden. They do not found any significant wage pressure on the destination country labour markets in fact growing economies, where the demand for labour is high (Ireland, UK, and Sweden).

Workers' migration decisions are likely to be influenced not only by the wage they expect to receive in the destination country but also by migration costs. ${ }^{25}$ Given

\footnotetext{
${ }^{23}$ In Table 2 we include only those studies, which address the endogeneity issue. It is moreover important to note that many of the non-instrumented studies find that a complementarity exists between immigrant and native labour, i.e. that the wages of natives tend to increase through labour migration. However, due to the methodological problems of measuring the impact of migration, a good deal of uncertainty surrounds the empirical findings.

${ }^{24}$ Some studies also report the elasticity between a percentage change in wages and the increase of the proportion of foreign citizens as a percentage, even though it is hard to interpret, as the proportion of immigrants varies greatly across countries and different time periods. The elasticity between an increase in wages and the proportion of foreign citizens of one per cent has been therefore converted at the sample-mean.

${ }^{25}$ Migration costs include not only the physical relocation costs but also employment uncertainty
} 
that workers trade the expected income increase off these costs, they migrate if the expected benefits arising from migration are higher than migration costs Sjaastad (1962). Generally, migration costs tend to be lower for highly skilled (Borjas 1994). In addition, migration costs are also decreasing in the stock of migrants from the sending region (Massey et al. 1987, Massey 1990, Carrington et al. 1996). Declining migration costs in turn widen the net wage gap between the source and destination countries and make it more attractive for migrants. Thus, theoretically, through declining migration costs, past migration has a positive impact on the next period's migration and, hence, a negative impact on human capital stock in sending country.

Empirical evidence suggests that among the major EU destination countries significant Diaspora is in Germany and France for Serbia and Montenegro, Italy and Greece for Albania. More recently, following the latest EU enlargements, Ireland, the United Kingdom and Sweden allowed free movement of workers from CEE countries. As a result, large communities of CEE migrants have been building in these countries creating migration networks for migrants from Poland, Lithuania, Slovakia and Latvia (Spain and Italy for Romania). Because of reduced social, economic, and emotional costs of migration, these migration networks make it considerably easier for the subsequent migrants to migrate.

\section{Conclusions}

Adopting the innovative capital framework of Kancs and Ciaian (2010), the present study examines the impacts induced by skill migration to the West on one of the key long-run growth determinants - knowledge capital - in the East European sending countries since the fall of the Wall.

Studying the impact of skill migration on education equilibrium in the sending countries, we find that, due to migration-induced adjustments in relative wages, the long-run education equilibrium in the East has been distorted by skill migration to the West. The scarce empirical data for CEE suggest that the two positive effects of high skill emigration on worker education (skilled/unskilled wage effect in Eastern sending countries, and the impact of remittances on liquidity constraints) have been stronger than the two negative effects (skill downgrading effect in Western destination countries, and skill and education cost heterogeneity).

Studying the impact of skill migration on long-run distribution of skilled labour force we find that skill emigration has been reducing human capital in the Eastern

(which is higher abroad than at home), social costs of leaving family and/or friends behind, cultural adjustment costs etc. 
sending countries since the fall of the Wall. However, the long-run impact of migration on human capital stock will be determined also by factors, such as the sending country's wage effect, and the destination country's wage effect, which most likely will reduce the short-run brain-drain effect in CEE. ${ }^{26}$ These findings are in line with Kancs (2005), who studies migration-induced wage effects in a general equilibrium framework and finds that adjustments in the CEE sending and destination country's wage rate have a negative impact on migration and, hence, a positive impact on human capital stock in the Eastern sending countries. In contrast, the evidence suggests that declining migration costs between the East and West is magnifying the direct brain drain effect which, as discussed above, is negative for human capital stock in the Eastern sending countries.

The empirical identification and quantification of skill migration-induced impacts on human capital in East European sending countries is complicated by two factors: the paucity of data and the specifics of Eastern Europe. For example, the facts that the East European economies are transforming from the central planning to market, they are relatively small and open, and they are receiving sizeable transfers from the West, considerably complicate the identification of skill migration-induced effects in the East.

Our results support policy recommendations suggesting that, if return migration policies are attractive enough, then returning migrants might increase the stock of human capital in a relatively short period of time. Furthermore, policies supporting "brain circulation" and temporary migration of highly skilled might help to mitigate the adverse effects of skill emigration. Hence, our key policy conclusion for CEE is, while focusing on reducing the outflow of the most talented and skilled, also improve the conditions for attracting back to home the previous migrants, many of whom have enhanced their skills while being abroad. This can be done e.g. through financial incentives; allowing for dual citizenship to migrant kids (which is prohibited in several East European countries); and by increasing the demand for highly skill workers in sending countries through higher public R\&D expenditure.

\section{References}

[1] Avato, J. (2009), Dynamics in Highly Skilled Migration: A European Perspective, $\mathrm{PhD}$ thesis, Eberhard-Karls-Universität Tübingen.

\footnotetext{
${ }^{26}$ Note that these factors are not exclusive and other, non-economic drivers of migration, which were not considered in the paper such as lacking infrastructure, political instability, distrust in domestic institutions, also affect migration decisions of individuals.
} 
[2] Beine, M., Docquier, F. and Rapoport, H. (2001), Brain Drain and Economic Growth: Theory and Evidence, Journal of Development Economics, 64, 275-289.

[3] Bhagwati, J. N. and Hamada, K. (1974), The Brain Drain, International Integration of Markets for Professionals and Unemployment: A Theoretical Analysis, Journal of Development Economics, 1, 19-42.

[4] Blanchflower, D., Saleheen, J., and Shadforth, C. (2007), The impact of recent migration from Eastern Europe on the UK economy, Bank of England.

[5] Borjas, G. J. (1987), Self-selection and the Earnings of Immigrants, American Economic Review, 77, 531-553.

[6] Borjas, G. J. (1994), The Economics of Immigration, Journal of Economic Literature, $32,1667-1717$.

[7] Borjas, G. J., Freeman, R.B. and Katz, L.F. (1996), Searching for the Effect of Immigration on the Labor Market, American Economic Review, 86, 246-251.

[8] Borjas, G. J. (1999), Economic Research on the Determinants of Immigration. Lesons for the European Union, World Bank - Working Papers.

[9] Borjas, G. J. (2001), Economics of Migration, International Encyclopedia of the Social and Behavioral Sciences, Elsevier, 9803-9809.

[10] Borjas, G. J. (2003), Welfare Reform, Labor Supply, and Health Insurance in the Immigrant Population, NBER Working Papers, 781.

[11] Borjas, G. J. (2005), The Labor-Market Impact of High-Skill Immigration,

[12] Butcher, K. and Card, D. (1991), Immigration and Wages: Evidence from the 1980's, American Economic Review, 81 (2), 292-296.

[13] Card, D. (2001), Immigrant Inflows, Native Outflows, And The Local Labor Market Impacts Of Higher Immigration, Journal of Labor Economics, 19(1), $22-64$.

[14] Card, D. (2005), Is the New Immigration Really so Bad?, Economic Journal, 115 (507), 300-323.

[15] Carrington, W. J., Detriagiache, E. and Vishwanath, T. (1996), Migration with Endogenous Moving Costs, American Economic Review, 86 (4), 909-930. 
[16] Cox, D. (1987), Motives for Private Income Transfers, Journal of Political Economy, 95, 508-546.

[17] Docquier, F. and Rapoport, H. (2004), Skilled migration: the perspective of developing countries, The World Bank, Policy Research Working Paper Series, 3382 .

[18] Docquier, F. and A. Marfouk (2006), International Migration by Educational Attainment (1990-2000), in Ozden, C. nd M. Schiff (Eds.), International Migration, Remittances and the Brain Drain, Palgrave-Macmillan.

[19] Drinkwater, S., Eade, J. and Garapich, M. (2006), Poles Apart? EU Enlargement and the Labour Market Outcomes of Immigrants in the UK, IZA Discussion Papers, 2410.

[20] European Commission (2007), Third Annual Report on migration and integration, Office for Official Publications of the European Communities, Luxembourg.

[21] Filer, R. (1992), The Effect of Immigrant Arrivals on Migratory Patterns of Native Workers, in Borjas and Freeman (Eds.), Immigration and the Workforce: Economic Consequences for the United States and Source Areas, 245-69.

[22] Furman, J. L., Porter, M. E. and Stern, S. (2002), The Determinants of National Innovative Capacity, Research Policy, 31 (6), 899-933.

[23] Gilpin, N., Henty, M., Lemos, S., Portes, J. and Bullen, C. (2006), The impact of free movement of workers from Central and Eastern Europe on the UK labour market, DWP Working Paper 29.

[24] Grossman, M. (1982), Government and Health Outcomes, American Economic Review, 72(2), 191-195.

[25] Hunt, J. (1992), The Impact of the 1962 Repatriates from Algeria on the French Labor Market, Industrial and Labor Relations Review, 45 (3), 556-572.

[26] IMF (2009), Balance of Payments Statistics, Washington.

[27] Kancs, D. (2005), Can we use NEG models to predict migration flows? An example of CEE accession countries, Migration Letters, 2(1), 32-63.

[28] Kancs, D. and Ciaian, P. (2010), Modelling the Flow of Knowledge and Human Capital: A Framework of Innovative Capital, International Journal of Public Policy, 6 (4), 219-247. 
[29] Kielyte, J., Kancs, D. (2002), Migration in the enlarged European Union: A perpective from the Baltic States, Journal of Baltic Studies, 33 (3), 259-79.

[30] Katseli, L.T., Lucas, R.E.B. and Xenogiani, T. (2006), Effects of Migration on Sending Countries: What Do We Know?, OECD Development Centre Working Papers, 250.

[31] Ledesma, M.L. and Piracha, M. (2001), International Migration and the Role of Remittances in Eastern Europe, Studies in Economics, 0113.

[32] Lowell, B. L. and Findlay, A. (2001), Migration of Highly Skilled Persons from Developing Countries: Impact and Policy Responses, International Migration Papers, 44, International Labour Office, Geneva.

[33] Lucas, R. E. B. (1988), On the Mechanics of Economic Development, Journal of Monetary Economics, 22, 3-42.

[34] Lucas, R. E. B. (2004), International Migration and Economic Development: Lessons from Low-Income Countries, Expert Group on Development Issues (EGDI), Stockholm, Swedish Ministry for Foreign Affairs.

[35] Massey, D. (1990), Social Structure, Household Strategies, and the Cumulative Causation of Migration, Population Index, 56 (1), 3-26.

[36] Massey, D., Alarcon, R., Durand, J. and Gonzalez, H. (1987), Return to Azatlan: The Social Process of International Migration From Western Mexico, Berkeley, University of California.

[37] Mattoo, A., Neagu, I.C. and Özden, C. (2005), Brain Waste? Educated Immigrants in the U.S. Labour Market, World Bank Policy Research Paper, 3581.

[38] OECD (2008), International Migration Outlook: SOPEMI - 2008, Organisation for Economic Co-operation and Development, Paris.

[39] Parsons, C. R., R. Skeldon, L. A. Winters and T. L. Walmsley (2005), 'Quantifying the international bilateral movements of migrants', Development Research Centre on Migration, Globalisation and Poverty, Working Paper T13.

[40] Patrinos, H. A. and Sakellariou, C. (2006), Cognitive Ability, Heterogeneity, Endogeneity and Returns to Schooling in Chile: Outcomes of the 1981 Capitation Grant Scheme, World Bank, Washington D.C. 
[41] Poutvaara, P. (2008), On human capital formation with exit options: comment and new results, Journal of Population Economics, 21 (3), 679-684.

[42] Schiff, M. (2005), Brain Gain: Claims About its Size and Impact on Welfare and Growth are Greatly Exaggerated, The World Bank, Policy Research Working Paper Series 3708.

[43] Sjaastad, L. A. (1962), The Costs and Returns of Human Migration, Journal of Political Economy, 70, 80-93.

[44] Traser, J.; Venables, T. (2005), Report on the free movement of workers in EU-25. Brussels: European Citizen Action Service.

[45] Wadensjö, E. (2006), Migration to Sweden from the New EU Member States, IZA Discussion Paper, 3190.

[46] World Bank (2000), Higher Education in Developing Countries: Peril and Promise, Report of the Task Force on Higher Education and Society, World Bank, Washington DC.

[47] World Bank (2006), Global economic prospects 2006: economic implications of remittances and migration, World Bank, Washington DC.

\section{Appendix}




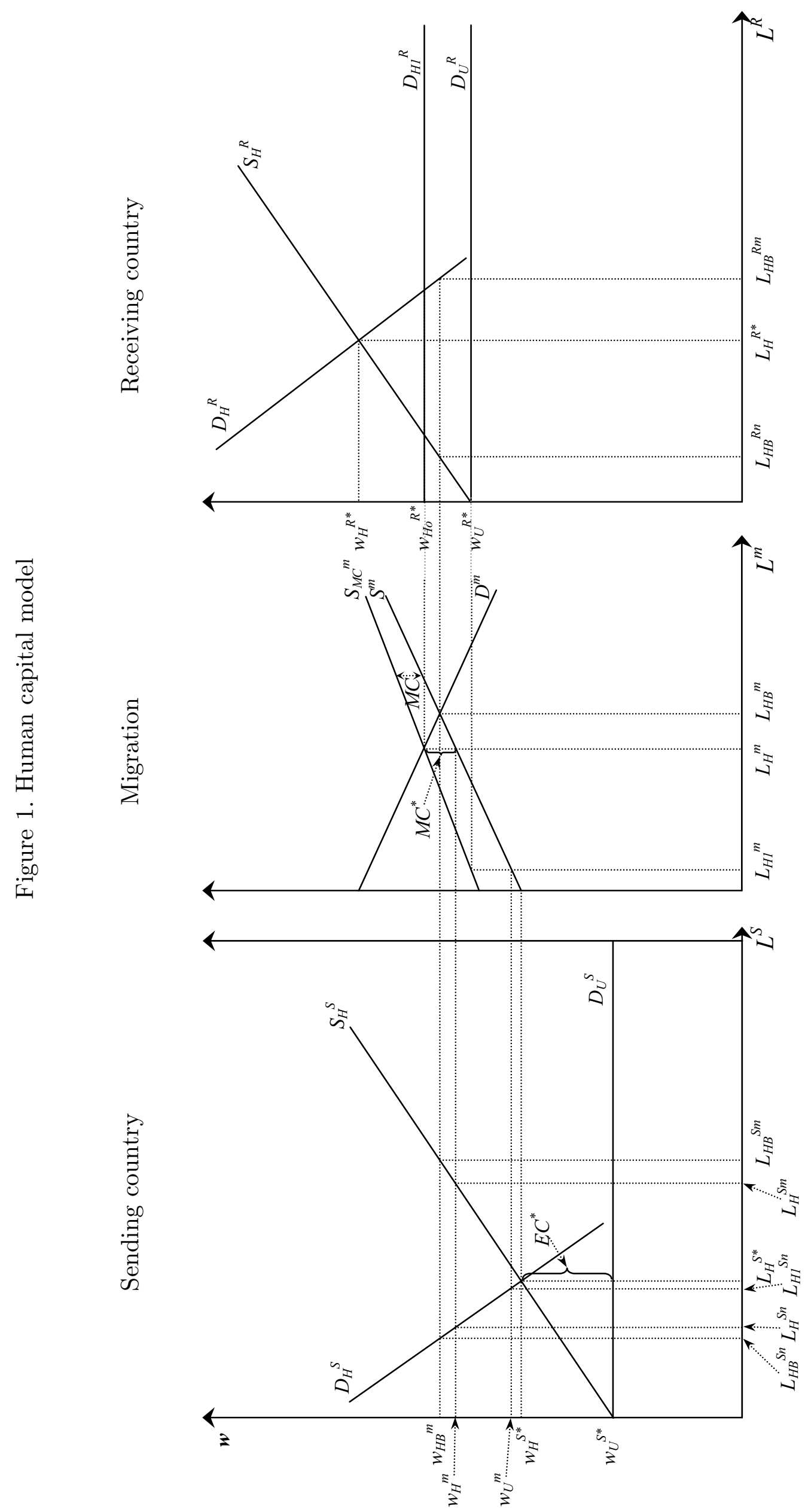


Figure 2. Knowledge model
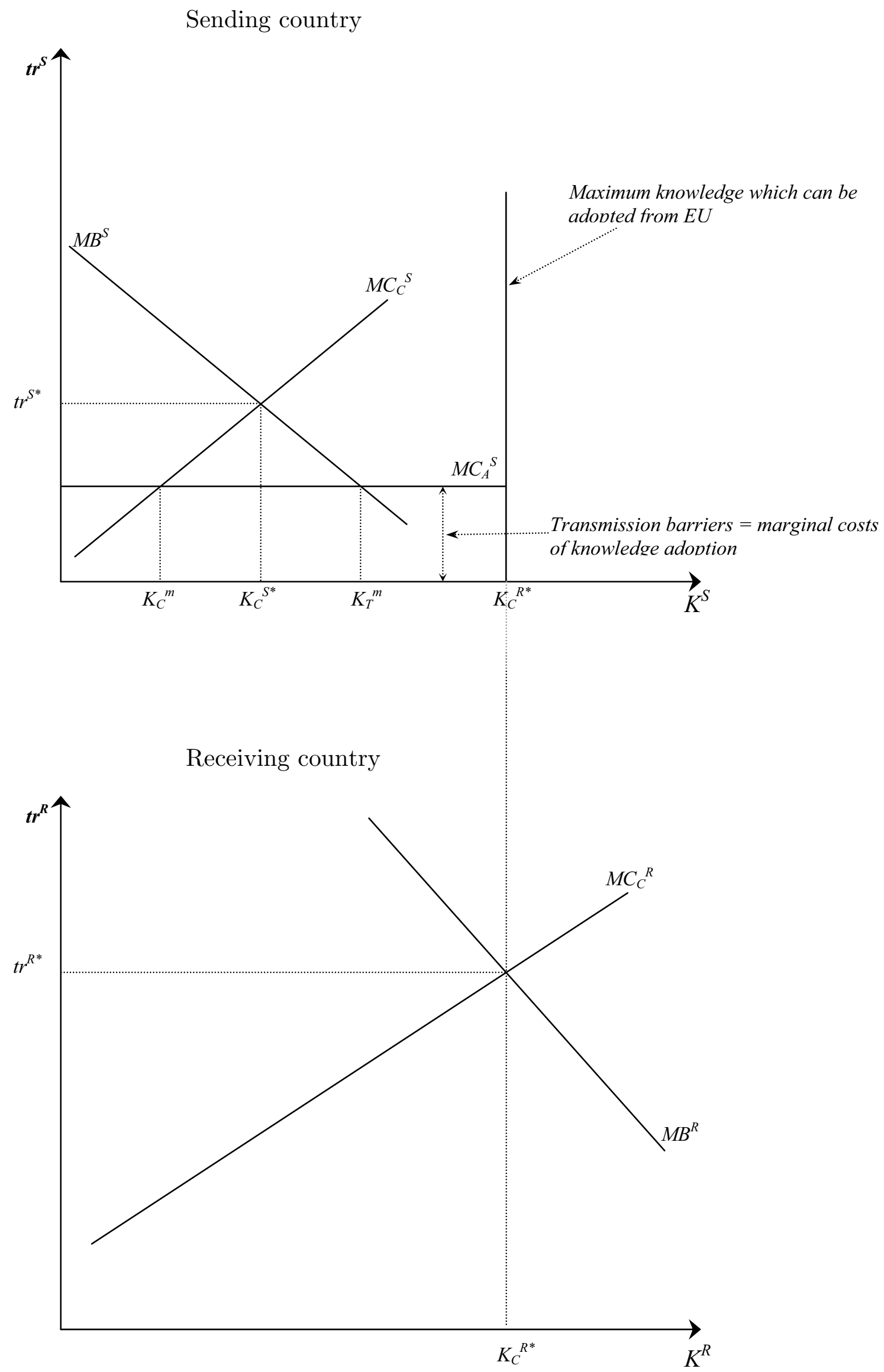